\title{
Excessive numbers of students in Medical Faculties, Analysis of Cumhuriyet University
}

\section{Tıp Faküiltelerinde Öğrenci Sayısı Problemi: Cumhuriyet Üniversitesi Analizi}

\author{
Dr. Öğr. Üy. Mustafa Karademir ${ }^{1}$, Dr. Öğr. Üy. Naim Karagöz ${ }^{3}$, Doç. Dr. Ahmet Altun ${ }^{1}$, Prof. Dr. \\ İlhan Cetin²
}

Cumhuriyet Üniversitesi Tıp Fakültesi Dekan Yardımcısı

Cumhuriyet Üniversitesi Tıp Fakültesi Dekanı

Cumhuriyet Üniversitesi Tıp Fakültesi Tıp Eğitimi Anabilim Dalı

Corresponding author: Ahmet Altun, MD., Cumhuriyet Üniversitesi Tip Fakültesi Dekan Yardımc1sı, Sivas, Turkey

E-mail: md.ahmetaltun@gmail.com

Received/Accepted: November 27,2018/December 28, 2018

Conflict of interest: There is not a conflict of interest.

\section{SUMMARY}

Medical education is one of the oldest and toughest trainings in the world. Regardless of the fact that it has ancient nature and serious stacking of experience in the medical education field, it is still a very dynamic process and incorporates unique difficulties in its presence. Like the other professional training, it is essential for the student to learn by observing and experiencing from the tutor directly. In this context, the balance between the numbers of tutor and the student is essential. In recent years, the number of medical faculties and the number of students increased dramatically all over the country, and the balance is disrupted significantly. In the light of this knowledge, we conducted a year based extensive analysis by using student and academic stuff records held by Rector's and Deans' offices to determine optimal student number of Sivas Cumhuriyet University. As a result, we managed to show that the numbers of medical students in Sivas Cumhuriyet University are over its capacity regarding academic stuff and infrastructure possibilities to give a proper education.

\section{ÖZET}

Tıp eğitimi dünyadaki en eski ve en zor eğitimlerden birisidir. Eski olması ve bu alanda çalışanların ciddi deneyimleri olmasına rağmen, hala çok dinamik bir süreç olan tıp eğitimi içerisinde birçok zorlukları barındırmaktadır. Diğer mesleki eğitimler gibi Tıp eğitiminde de kişinin ustasından direk görerek ve deneyimleyerek öğrenmesi esastır. Bu bağlamda öğretici ve öğrenci sayıları arasındaki denge elzemdir. Son yıllarda ülke çapında Tıp Fakültesi öğrenci sayıları artmış ve bu denge ciddi anlamda bozulmuştur. Bu bilgiler 1şı̆̆ında Sivas Cumhuriyet Üniversitesi olarak öğrenci sayının objektif kriterlere göre belirlenmesi için yapılan bu çalışmada, Tıp Fakültesi ve Rektörlük öğrenci işlerinden elde edilen sayısal veriler kullanılmış ve yıllara göre analiz edilmiştir. Sonuç olarak Sivas Cumhuriyet Üniversitesinin öğrenci sayısının alt yap1 ve öğretim üyesi sayısına göre fazla olduğu ve etkin bir eğitim-öğretim yapılabilmesi için bu sayının düşürülmesi gerektiği sonucuna varılmıştır.

Anahtar sözcükler: Tıp Eğitim, optimal öğrenci sayısı

\section{INTRODUCTION}

In Sivas, which was defined as a university city eight hundred years ago, once again believed in the need for a university, the city started working on this issue in 1966 and by this idea, it established the "Sivas 4 Eylül University
Construction and Survival" Association and in 1971. The association shared its working plans to the parliament of the period.

A draft law on the occasion of the 50th anniversary of the establishment of the Republic of Turkey by the Grand National Assembly of 
Turkey was presented to the parliament by members of the government and within the framework of the eternalization of its 50th anniversary, it proposed to establish a university in a province without a higher education establishment in Anatolia. As a result of the meetings held in Ankara by the members of the association, if a university will be established in Anatolia in the 50th anniversary of the foundation of the Republic; the location of this university should be Sivas; because the province where the foundation of the Republic was laid is Sivas. Mustafa Kemal Atatürk, the great leader, visited Sivas in 1923 and stated the location of Cumhuriyet University with the saying of "We laid the foundation of the Republic here". Article $5 / \mathrm{b}$ of the Law No. 1701, published on the 5th of April, 1973, stated the following provision: On the occasion of the 50th anniversary of the founding of the Republic, it was decided to establish a university with the name of "Cumhuriyet University" in order to begin teaching on 29 October 1973 in the first faculty of Sivas. In October 1973, the subject was interviewed by the Rector of Hacettepe University, Prof. Dr. İhsan DOĞRAMACI and on October 20, 1973, the Hacettepe University Senate held its first faculty under the decision of 73 / A-95. and unanimously agreed to be opened and supported. He was appointed as the Founding Dean of the Faculty of Medicine at Cumhuriyet University. Dr. Yılmaz SANAÇ was appointed and again with the decision of the Senate, 50 students were enrolled in the 1973-1974 academic year and began their education in Hacettepe University Faculty of Medicine.

This journey, which started with fifty students, continued with growing and maturing with the efforts of many valuable people, and finally, Cumhuriyet University Faculty of Medicine as a strong service center with accredited medical education and high-quality physician training center and all units with a capacity of 1060 beds is a significant health force.

The aim of this study is to make a situation analysis and to offer solutions to the problem of the exceeded number of students, one of the common problems in the Faculties of Medicine, from the perspective of Cumhuriyet University Faculty of Medicine.

\section{MATERIAL AND METHODS}

The data used in this study was based on the archives of the Faculty of Medicine. Data such as the number of faculty members, the number of students, number of residents, number of classrooms and capacity, laboratory facilities were obtained from prepared annual activity reports and strategic plans. In the study, data between the years 2007-2018 were used to confirm the validity and reliability of the data.

\section{FINDINGS AND DISCUSSION}

When the number of faculty members at Cumhuriyet University Faculty of Medicine is examined in the last ten years; It is seen that the number of professor faculty members who were 63 in 2007 was up to 100 in 2012-2013, but after that date, it was identified as 87 in 2018. Over the years, the number of associate professor faculty members has remained very stable in the $40-50$ band. The possible reason for this is that since the period of application for an associate professorship (about 4-5 years) after being an assistant professor and the time period after being associate professorship to full professor (5 years) is similar. Because of this reason, the positions opened due to the promotion of associate professors to a full professor is usually filled with an assistant professor who has been just promoted to associate professor. When the time-dependent change in the number of assistant professor faculty members is examined, a fragile distribution with an upward trend is observed. This is not surprising given the nature of the position is thought. When we look at these three positions in general, it is seen that the numbers increased significantly compared to time. Especially in 2011, a significant peak is observed in numbers, which is an important fact when the time interval is correlated with the number of students (Table 1, Figure 1) ${ }^{1}$.

Table 1. Distribution of the number of Faculty Members of Faculty of Medicine of Cumhuriyet University between 2007-2018 


\begin{tabular}{|l|l|l|l|l|l|}
\hline \multicolumn{3}{|l}{ Academic Stuff } & & & \\
\hline Year & Professor & $\begin{array}{l}\text { Associate } \\
\text { Prof }\end{array}$ & Assistan Prof & Specialist & Branch Assistant \\
\hline $\mathbf{2 0 0 7}$ & 63 & 48 & 60 & & \\
\hline $\mathbf{2 0 0 8}$ & 69 & 49 & 56 & 2 & \\
\hline $\mathbf{2 0 0 9}$ & 66 & 48 & 62 & 2 & \\
\hline $\mathbf{2 0 1 0}$ & 67 & 48 & 51 & 2 & \\
\hline $\mathbf{2 0 1 1}$ & 71 & 47 & 59 & 5 & 8 \\
\hline $\mathbf{2 0 1 2}$ & 88 & 45 & 67 & 4 & 8 \\
\hline $\mathbf{2 0 1 3}$ & 94 & 47 & 85 & 6 & 16 \\
\hline $\mathbf{2 0 1 4}$ & 100 & 41 & 80 & 11 & 5 \\
\hline $\mathbf{2 0 1 5}$ & 100 & 40 & 82 & 13 & 2 \\
\hline $\mathbf{2 0 1 6}$ & 89 & 41 & 65 & 5 & 1 \\
\hline $\mathbf{2 0 1 7}$ & 91 & 42 & 82 & 9 & 1 \\
\hline $\mathbf{2 0 1 8}$ & 87 & 41 & 64 & & 4 \\
\hline
\end{tabular}

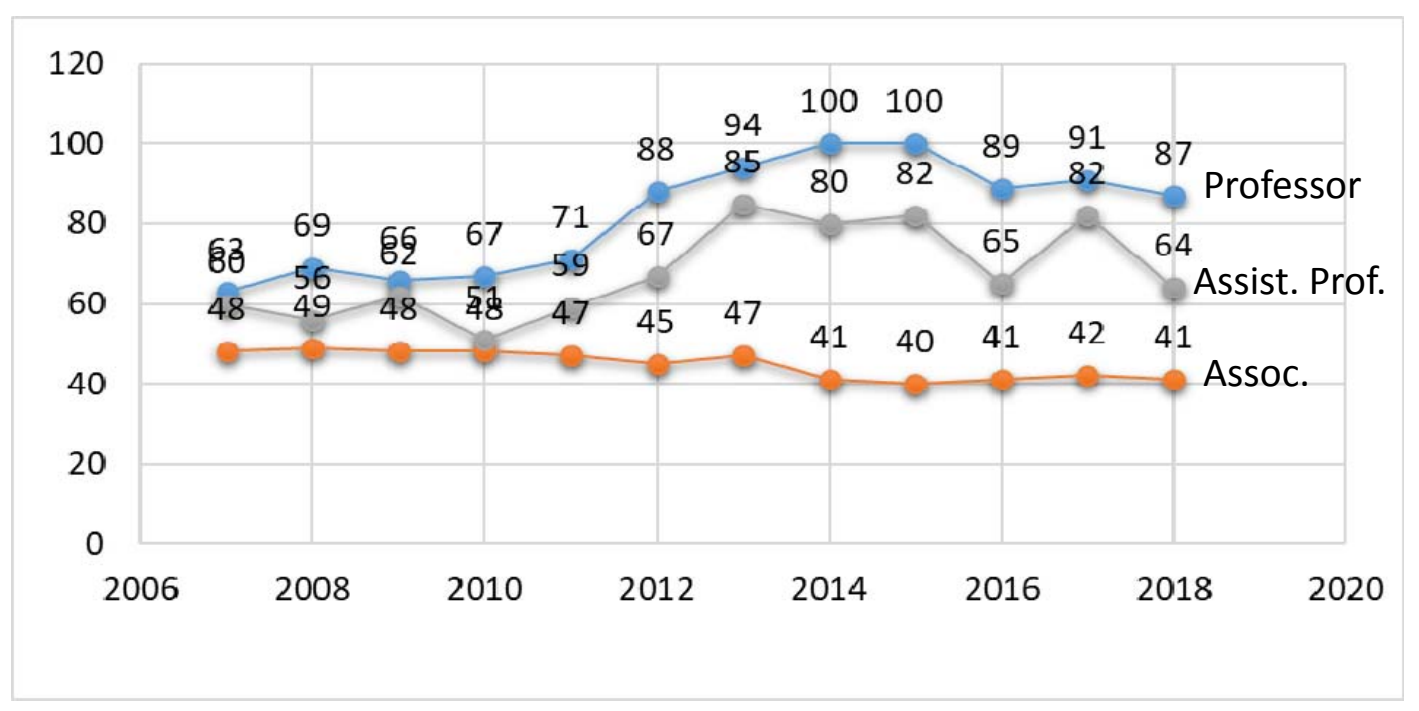

Figure 1. Distribution of the number of Faculty Members of Faculty of Medicine of Cumhuriyet University between 2007-2018

The increasing trend in the numbers of faculty members was not limited in Cumhuriyet University, all of Turkey, especially in Medical
Sciences and Basic Medical Sciences visibly since 2011 in the number of faculty members in the area occurred an increase (Figure 2) 


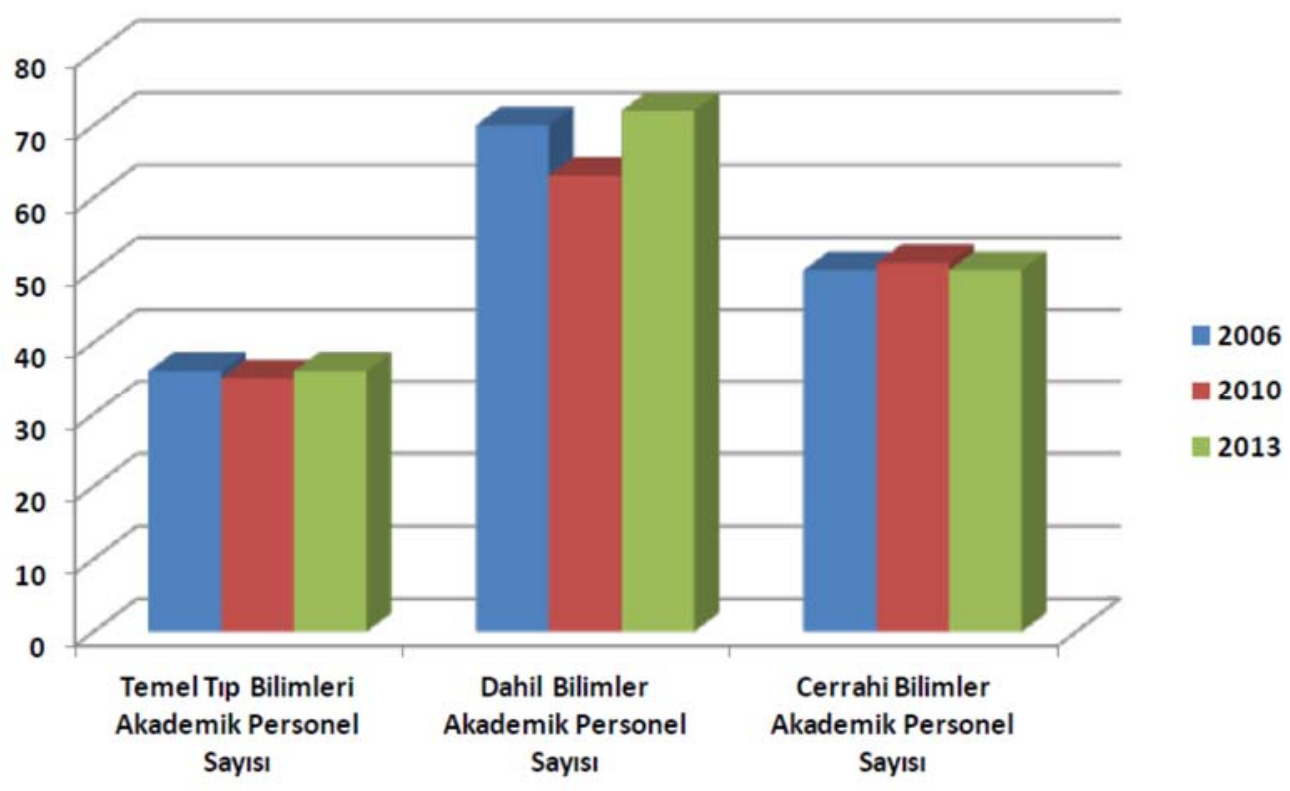

Figure 2. Turkish Medical Students Association "Impact of Increasing Faculty of Medicine Quotas on Medical Education", $2014^{2}$.

When the distribution of the total number of students of Cumhuriyet University Faculty of Medicine is examined by years, we see that the number of students increased from 816 to 1150 in 2011 after a long period of stability (Figure 3).
The most important dynamics behind this increase trend is that the Higher Education Institution (YÖK) is thought to have a quota increase starting from 2008, especially in 2010-2011.

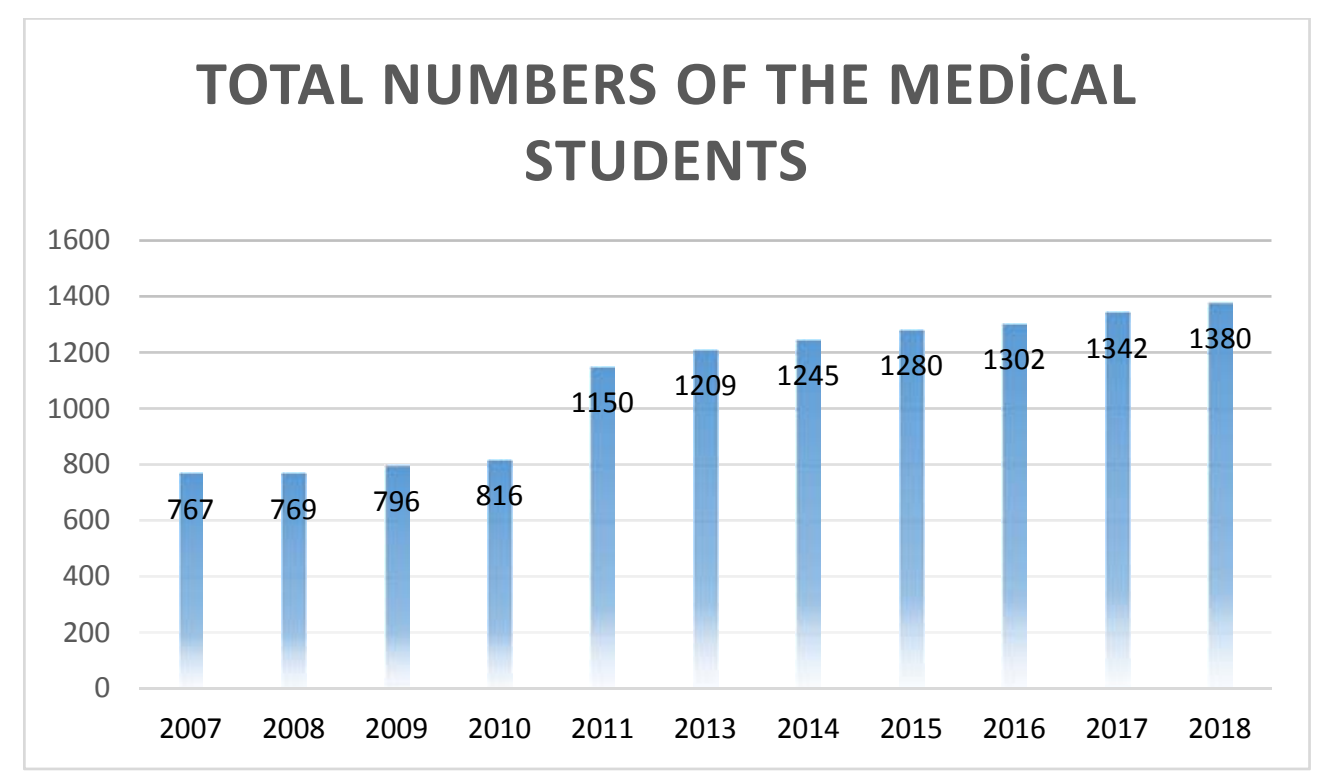

Figure 3. Year-on-year change of the total number of students of Cumhuriyet University Faculty of Medicine between 2007-2018

The quota increase and the consequent increase in the total number of students of the Faculty of Medicine has just occurred in Turkey, all the tables have a similar affect our university (Figures 4 and 5). 


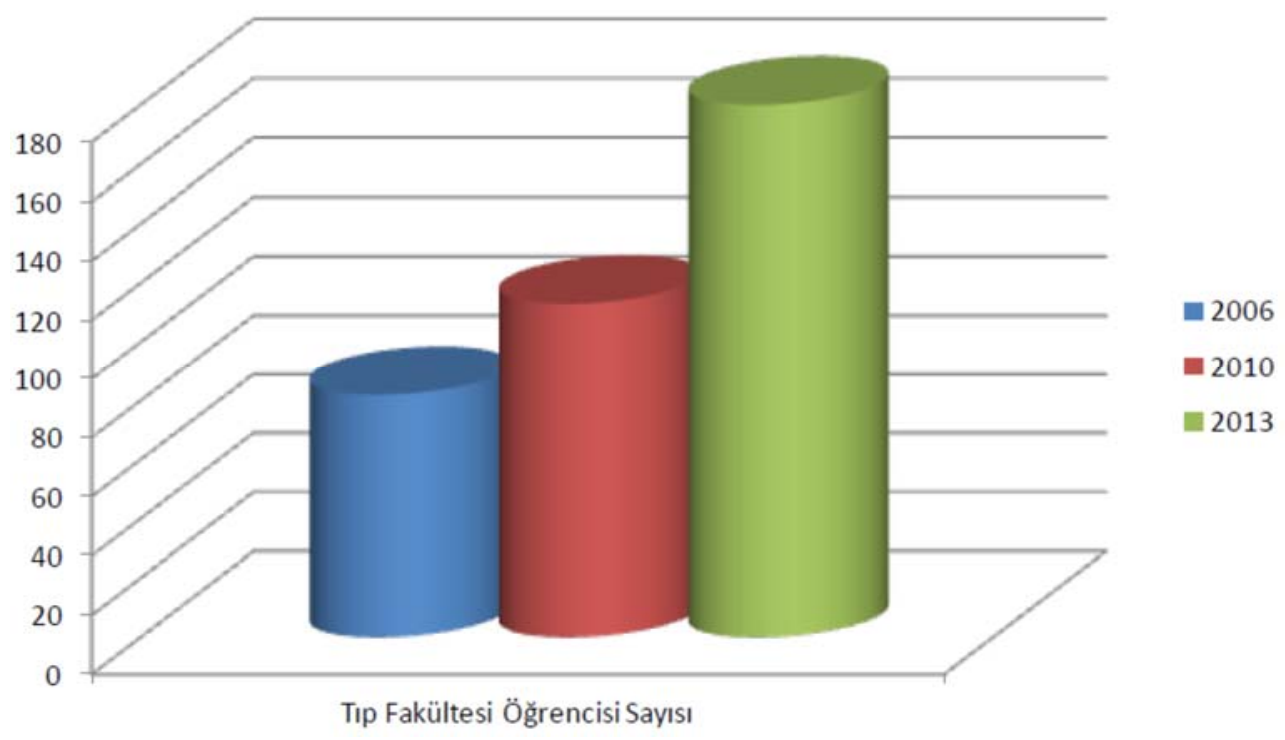

Figure 4. Turkish Medical Students Association Tip Impact of Increasing the Quotas of Medical Faculty on Medical Education, 2014.

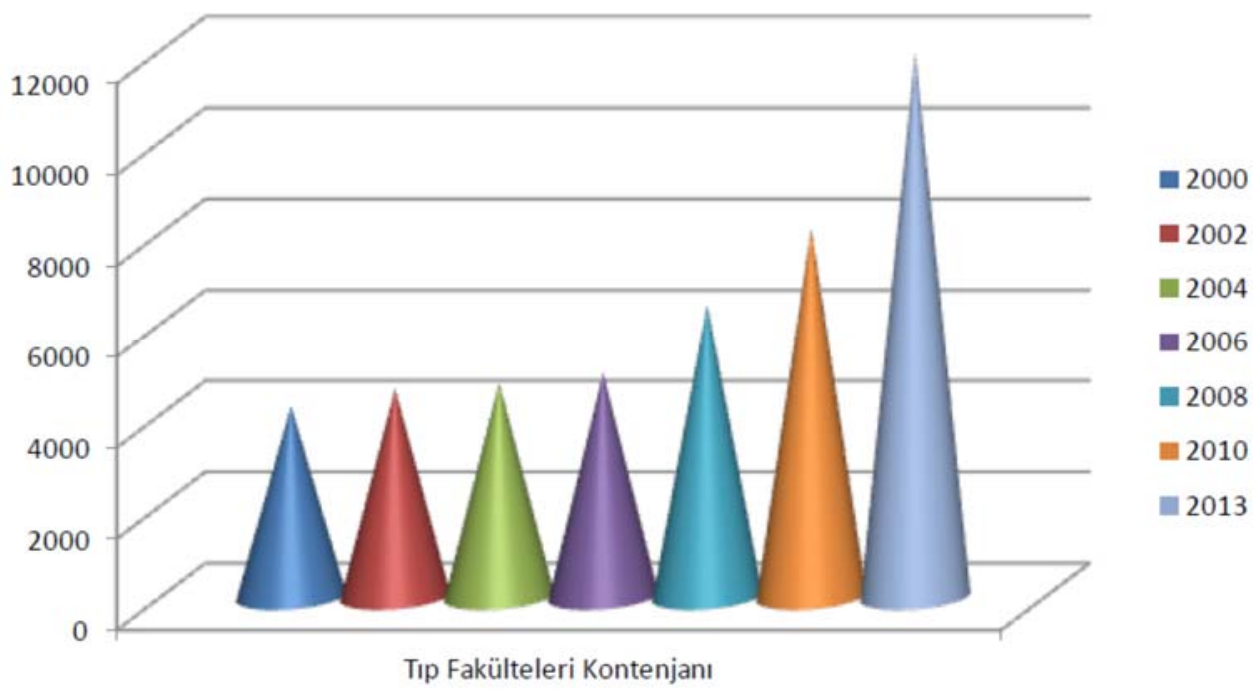

Figure 5. The quota of Faculty of Medicine; The report of Turkish Medical Students Association named "Impact of Increasing the Quotas of Medical Faculty on Medical Education", 2014 3.

From the above analysis, both the number of faculty members and the number of students have increased both in Cumhuriyet University Faculty of Medicine and all other faculties of medicine since 2010-2011. However, one of the most important parameters, in order to determine whether the increase in the number of faculty members is sufficient, is the number of faculty members per student. When the number of faculty members per student in Cumhuriyet University Faculty of Medicine is evaluated, it is seen that the ratio decreased from 0.22 to 0.14 . This meaningful decline means that a sufficient number of students cannot be provided (Figure 6). 


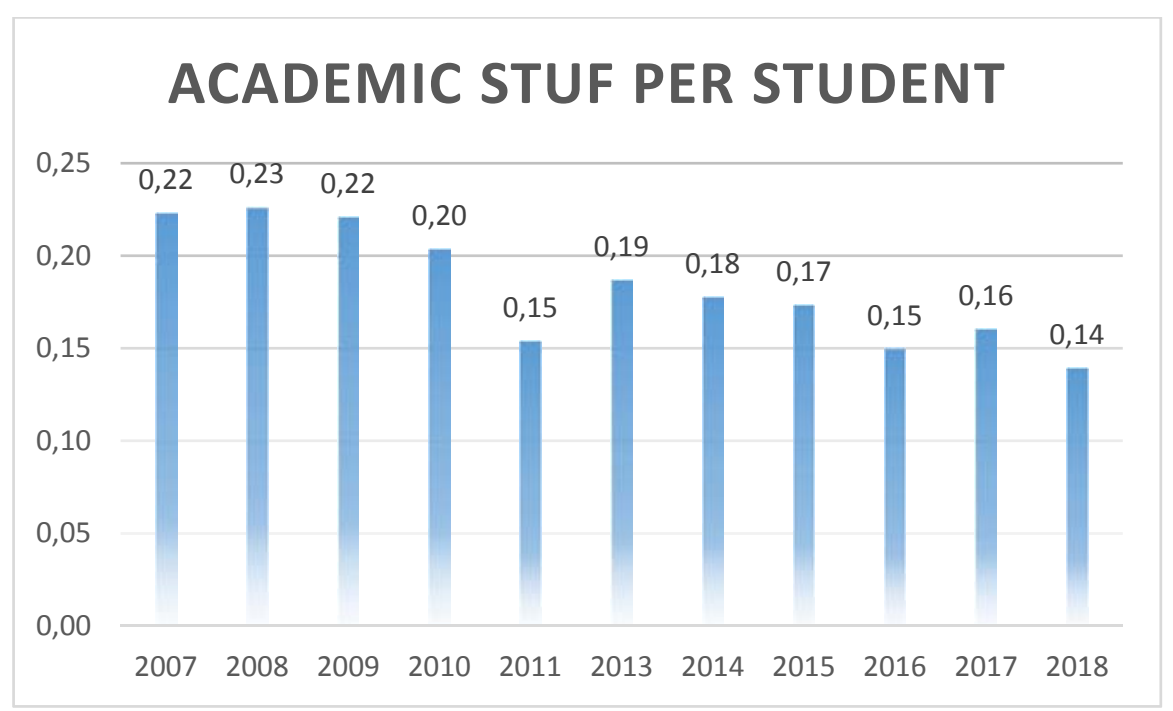

Figure 6. Number of faculty members per year in Cumhuriyet University Faculty of Medicine.

One of the most important factors for the internship in medical education, especially in clinical training, is assistants. The relationship between the number of assistants or the number of assistants and the number of assistants in the faculty is very important, especially in terms of providing clinical practical training and developing the art of medicine. As can be seen from the figure below (Figure 7), although the number of students has increased dramatically, the number of assistants has hardly changed in the last decade. This makes the education of the students difficult and also increases the routine burden on the faculty member and significantly restricts the time that the instructor should devote to the training activities.

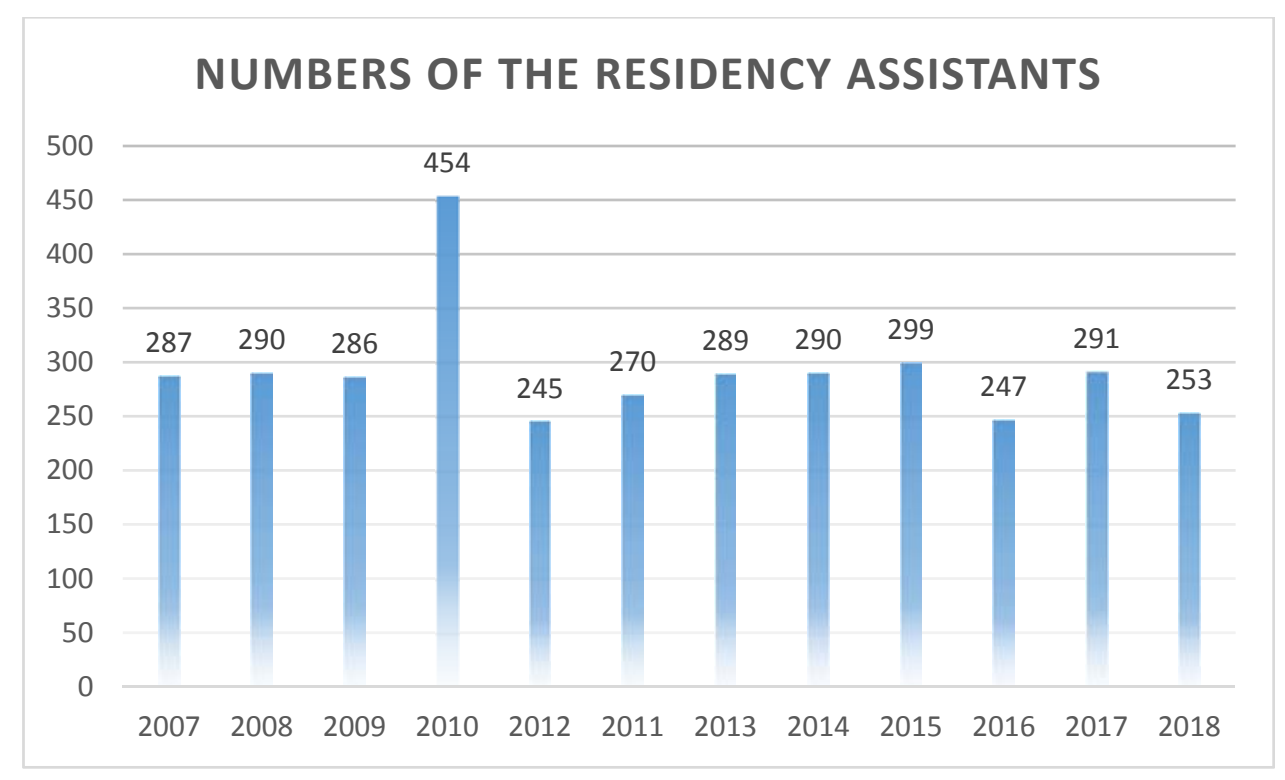

Figure 7. Distribution of residency assistant numbers between the years 2007-2018 of Cumhuriyet University Faculty of Medicine according to year

One of the most important factors affecting the quality of education is the amount and adequacy of the physical education areas and educational materials. The Faculty of Medicine of Cumhuriyet University consists of a morphology building, a classrooms building and, finally, the Educational 
Research Hospital buildings. There are 5 large amphitheaters, 25 Problem Based Learning (PDÖ) classrooms, 2 meeting rooms, 2 multidisciplinary laboratories, 1 simulated patient training area, and 1 simulation laboratory in the basic sciences building. There are 6 classrooms for 50 people and a conference hall for 300 people. There are 4 classrooms of 50 people in the area of the faculty members in the hospital building and meeting rooms in the services. There is also a conference hall for 200 people in the hospital building. These training areas have been existing for a long time and in the last 10 years, the biggest increase in the education areas was realized with the class building in 2014. In spite of the fact that the physical infrastructure has been repaired and developed, the infrastructure we already have is not sufficient for us to perform the education activities that are increased and diversified with the accreditation of our Faculty of Medicine. At the end of each semester, the feedback received from the students in the educational evaluation meetings indicates the high number of students.

In conclusion; As a result of the projections, it was calculated that the total number of students should be less than 535 students in order to ensure that the number of faculty members per student is 0.22 , which could be provided even in 2007 when the number of infrastructure deficiencies, number of assistants, and many other reasons have been set aside. Since this number cannot be reduced in such a dramatic manner, it is reasonable to reduce this number by approximately 100 students each year in the next 5 years and to reach the desired figures after 5 years. In this context, it is necessary to reduce the quota of Cumhuriyet University Faculty of Medicine to 95 students and to protect this quota in this way in the coming years. It is necessary to reduce the number of students not only to increase the quality of education but also increase the number and quality of faculty members, increase the number of assistants and increase the capacity and quality of physical spaces in the process.

\section{REFERENCES}

1. Sayek İ, Odabaşı O, Kiper N. Türk Tip Tabipleri Mezuniyet Öncesi Tip Eğitimi Raporu., 2010.

2. TURKMSIC. Turkish Medical Student's International Committee. Turkish Med Student's Int Comm 2014;1:1-4.

3. The quota of Faculty of Medicine; The report of Turkish Medical Students Association named "Impact of Increasing the Quotas of Medical Faculty on Medical Education" , 2014 